\title{
Ka Rangona te Reo: The Development of Māori-language Television Broadcasting in Aotearoa New Zealand
}

\section{Introduction}

New Zealanders today can hear Māori language broadcast in a variety of contexts: on Māori Television and to a lesser extent on state-owned TV1, TV2 and privately-held TV3, on digital platforms and via broadcasters' programmes-on-demand internet sites. However, these opportunities are a relatively recent development spurred by years of agitation by Māori about the decline of te reo Māori in an English-saturated world and the recognition that the powerful medium of television broadcasting could help promote, protect and enhance reo and tikanga.

Māori-language television broadcasting is largely Government-funded, a support forced on the state as Māori successfully claimed their rights to representation under the Treaty of Waitangi. This literature review starts by canvassing the genesis of television in New Zealand and the limited contexts it provided for te reo Māori. It then describes grassroots political activism by Māori seeking a space for tikanga and reo Māori, and successful claims against the Government.

We then trace the legislation that gave te reo Māori a place on the small screen and led to the birth of the country's first indigenous channel. Finally, this review briefly explores the expansion of reo Māori programming and platforms as Aotearoa New Zealand faces a very different broadcasting landscape.

This literature review will not cover the development of Māori-language radio broadcasting, though many of the developments, especially those spurred by protest and subsequent legal action, are linked. For overviews on the growth of radio in te reo, see authors such as Patrick Day, Karen Neill, 
Morris Shanahan, Te Puni Kōkiri, the Waitangi Tribunal and others.

\section{Ka Tìmatanga: The Early Days of Television and te Reo Māori}

New Zealand's first television broadcast took place on June 1, 1960. The New Zealand Broadcasting Service's sole channel, AKTV-2, beamed some overseas serials over VHF and presented a live variety show featuring, among others, Rotorua entertainer Howard Morrison (Boyd-Bell, 1985). Morrison was a conversational but not a fluent speaker of Māori (TVNZ, 2009) and he was, by then, one of a rapidly shrinking breed; the survival of te reo Māori was seriously threatened.

Numerous authors have described how massive social change fuelled a decline in Māori speakers in the 20th century, among the contributing factors urbanisation, repressive proEnglish education policy and practise, and beliefs among Māori and Pâkehā about the greater value of English (King, 1993; Benton 1984; Belich, 2001).

The important Hunn report, which brought Maori socioeconomic issues to public attention (Hunn, 1960), considered the language moribund:

... Language, arts and crafts, and the institutions of the marae are the chief relics. Only the Māoris can decide whether these features of their ancient life are, in fact, to be kept alive; and in the final analysis, it is entirely a matter of individual choice (p. 15).

By the late 1960s, says Benton (1997), "it was quite clear that Māori had ceased to be the language of socialisation for most Māori families" ( $p$ 24). Worse, te reo Māori was, by the 1970s:

... Playing only a very marginal role in the upbringing of Māori children ... if nature were left to take its course, Māori would be a language without native speakers with the passing of the present generation of Māori speakers ( $\mathrm{p}$. 12). 
The dominance of English on the airwaves was another factor hastening the decline. "The medium unremittingly whispers, shouts and displays its message - 'Get with it, only English really counts" (Benton, quoted in Hubbard, 2004, p. C1). Fox (1993) says that te reo Māori "has been brought to the brink of extinction more than anything else by the influence of monolingual broadcasting" (p. 266).

Meanwhile, the small screen was rapidly entering New Zealand homes, presenting a largely Pākehā world for Pākehā (Stephens 2002; Fox 2002). There were television programmes on Māori subjects in the 60s, primarily on Māori music, dance and art or featuring Māori entertainers, says Stephens (ibid): "Certainly, the earliest Māori programmes tended only to be presentations of Maori in performance" (p 108). Among these shows were Songs of Their Forefathers (1965) and the musicand-dance series Pupuri Rā (1970). (Boyd-Bell, 1985).

However, there were occasional and notable departures. In 1974 , for example, an independent production of the legend of Uenuku was presented entirely in Māori, leading reviewer Rev Kingi Ihaka, writing in the Auckland Star newspaper, to call for more regular Māori programming on television (Boyd-Bell, 1985).

Ihaka was one of a growing number of people who recognised the power of broadcasting and wanted change. The 1960s and early 1970s saw the flowering of activism that protested the Government's assimilationist policies. Among these groups was Auckland-based Ngā Tamatoa, which grew out of the University of Auckland Young Māori Club (Meredith, 2009; Te Rito, 2008; Belich 2001; King 2003) and the Victoria University-linked Te Reo Māori Society, which had a particular interest in the media's handling of Māori issues (King, 2003). It was these two groups, led by Hana Jackson of Ngā Tamatoa and Lee Smith of Te Reo Māori Society, which in September 1972 presented a 30,000signature petition to Parliament calling for te reo and tikanga Māori to be promoted in schools. (Meredith, 2009; Te Rito, 2008).

New Zealand got its second VHF television channel in 1975; Television One ran light entertainment shows (Boyd-Bell, 1985; Ministry of Commerce, 2007). The two channels were run by separate public corporations, leading to a flurry of competitive behaviour (Boyd-Bell, 1985; Horrocks, 2002; Morris, 2004). 
However, the next year, the Government's Broadcasting Bill, which aimed to merge separate radio and television broadcasting services into a new organisation called the Broadcasting Corporation of New Zealand (Spicer, Powell and Emanuel, 2002), gave Māori a chance to be heard in a public forum. The New Zealand Māori Council, then chaired by Graham Latimer, made submissions on the Bill, calling for a weekly TV programme covering Maori and Polynesian affairs, a series of simple, fiveminute education programmes aimed at Māori, and a Māori radio station (Boyd-Bell, 1985).

Several broadcasts in the 1970s showed understanding of the need for increased Māori content beyond Māori dance and song, among them the 1974 English-language documentary series Tangata Whenua, directed by Barry Barclay and presented by Michael King (Fox 2002; Stephens, 2002; Reweti, 2006). But on the whole, broadcasts reflecting Māori were rare (Stephens 2002; Fox 2002). In the 1970s, says Stephens (ibid.):

... Māori people were rarely seen on television ... the Māori language was almost never heard on the airwaves, and the whole spectrum of social and political issues important to Māori people were largely ignored both by radio and TV (p 261).

There were, says Dunleavy (2008), "shamefully few programmes which, because they were also written, produced and or directed by Maori personnel, were appropriately informed by Maori values and perspectives" (p 802). This situation prompted another Te Reo Māori Society petition to Parliament in 1978, this one a 25,000 signature call for a recognisable Māori presence on television, in particular a Māori team within the national broadcaster to initiate and create Māori programmes, to deliver a prime-time news bulletin in te reo, to advise on Māoritanga and to add a Māori dimension to regular viewing (Boyd-Bell 1985; Young 1978). However, efforts to promote Māori language on television remained sporadic. TV1, for example, ran programme summaries and continuity announcements in te reo with English subtitles for Maori Language Week in 1979 (ibid., p. 198). 
This is the point at which we should touch on the large body of work done on the representation of Māori in the media. Numerous authors (among them Walker 1990b; Spoonley 1990; McGregor 1991; Fox 1992; Abel 1997; Kupu Taea: Media and Te Tiriti Project 2007; Archie 2007) have documented how Māori representation in the media has often been stereotypical and negative, driven by the entrenched, subjective and negative news values of a largely monocultural media with little understanding of the Māori world. The end result was, and still can be, a representation "which often has an emphasis on conflict, on the bad news and defines Māori in problem terms" (McGregor, 1991, pp. 6-7).

Derek Fox (2002) explains how the mainstream media's portrayal of Māori as "The Other" manifests itself:

... The standard procedure is to pay little attention to Māori activities except as they impinge on the Pākehā (white) establishment. So crime and land claims get publicity, as do achievers in sport and show business, although the Māori element in the success stories is likely to be played down. Losers may be Māori, but winners are New Zealanders (pp. 261-262).

Such a negative portrayal of Maori is strongly tied to the reclaiming of Māori identity and the push for media where Māori could redefine news values and speak with their own voices, not through a monocultural construct (McGregor 1991; Stuart, 2003).

The first regular Māori programme shown in prime time (NZ on Screen, 2010), though not in te reo Māori, was Koha (1980-1985), a 30-minute, Sunday afternoon, Englishlanguage magazine programme (Boyd-Bell 1985; Fox 2002). The programme started in a $4 \mathrm{pm}$ Sunday slot on TV1 but by mid-1981 had moved to $6 \mathrm{pm}$ on Mondays and then to a prime Sunday $6.45 \mathrm{pm}$ slot. According to NZ on Screen, (2010), it explored issues ranging from social problems and food preparation to tribal history, natural history, weaponry, Māori art and te reo. It was a window into te ao Māori for Pākekā, and a link to urban Māori estranged from their culture. 
However, several authors document a disconnect between TVNZ expectations of Koha and what its reporters perceived as appropriate. Fox said that the programme was "a soft, cute window on Māori society through which Pākehā people could peer" (2002, p 262). Tainui Stephens describes working as a Koha reporter in 1984 (p. 108):

...Our bosses were Pākehā, and they believed that Māori programmes should provide a 'window' onto the Māori world. Looking back, I take this to mean that our programs were wanted in order to display and explain ourselves to people who were not Māori (p 108).

Debra Reweti (2006), who was also a Koha reporter in 1984, says staff didn't necessarily share this view, feeling:

...An obligation to speak directly to Māori with an authentic voice ... early Koha staff members ... sought to grab the Māori audience in an academic headlock if necessary to ensure Māori stories were listened to and appreciated ( $\mathrm{p}$ 180).

Boyd-Bell (1985) says that Koha was given "financial, staff and technical resources on a par with other regular peak-time programmes" ( $p$ 198), but this view is contradicted by Fox (2002), who says a "grudging, minimalist attitude" to Koha was reflected in its "low-cost approach" (p. 263).

In the early 1980s, the educational shows Körero Mai and Te Reo were designed to teach te reo to beginners (Stephens, 2002), and Fox (1993) views 1982 as something of a watershed year. That year he was a Close-Up reporter, and for Māori Language Week was asked to present a nightly two-minute news programme in Māori just before the main $6 \mathrm{pm}$ news on TV1. Fox ignored the brief to simply translate and present the general news of the day and with two helpful friends - but no other resources - set out to collect Māori-focused news:

... Each day we begged, borrowed and purloined facilities to gather, edit and transmit film stories of Māori news (p. 103). 
The novelty of a bulletin delivered entirely in te reo raised questions about why such programming wasn't more regular, and Fox (ibid.) says that the then Minister of Broadcasting, Ian Shearer, "told me privately that he would take up the cudgels on behalf of a regular Māori news broadcast" (pp. 263-264). That broadcast was the country's first regular Māori-language news programme, Te Karere, which went to air in February 1983 with Fox and Whai Ngata as hosts.

The pair shared the roles of presenter, editor, reporter and producer; Te Karere started without researchers, back-up staff, or a camera team (Walker, p 272). Although Stuart (2003) argues that the show was "symbolically important" (p. 51 ), its birth was mired in dispute about the lack of resources, which network it should call home, and what time it should broadcast. Eventually, Te Karere ran for four minutes on TV2 at 5.55pm. (Fox 1990b, 2002; Boyd-Bell 1985; Stephens, 2002).

The workplace was a hostile environment (Harawira, 2008). Camera crews referred to Te Karere jobs as the "coon round" and according to Reweti (2006) mainstream reporters resented the programme's use of resources:

... I can recall a respected Pākehā news reporter spinning on his heels angry that he had to wait for a Te Karere item to be edited, saying loud and clear 'F_kin' jungle bunnies' - the general attitude was that Māori programmes were of high nuisance value and minimal importance (p. 182).

However, Te Karere, which was later extended to 10 minutes, was putting te reo firmly on screen. According to Fox (1993), "as a daily dose of fluent, accurate Māori, Te Karere has always made a priceless contribution simply towards preserving the Māori language" (p. 266). Te Karere also set the scene for updating te reo for a modern era (Harawira, 2008).

\section{He Wero: Staking Claims}

The broadcasting sector had been heavily regulated and regularly restructured up to the 1980s. However, the Labour 
government that assumed power in 1984 was determined to liberalise the economy and had broadcasting in its sights (Horrocks, 2002). In 1985, the Broadcasting Tribunal, responsible for allocation of radio and television licenses, called for applications for a third television channel, and Māori saw an opportunity. The New Zealand Māori Council, then led by Graham Latimer, formed the Aotearoa Broadcasting Trust to pitch for the warrant under the name Aotearoa Broadcasting Systems (ABS) (Walker, 1990; Fox 1990a).

Whatarangi Winiata, a Victoria University accounting professor who had served a term on the Broadcasting Corporation of New Zealand board, was asked to lead the team compiling the application. The proposal was that ABS would produce two-thirds of the programmes it transmitted, of which half would be in te reo (Fox, p 131). The trust lacked the financial resources of the seven other applicants (Fox p131; McRae 1986/87), but broad backing from Māoridom - and the argument that BCNZ still owed Māoridom a great deal convinced the corporation to negotiate a deal that would cover a large proportion of initial costs should the pitch be successful (McRae 1986/87; Walker 1990; Fox 1990a).

However, raising the rest of the money needed was harder, and Fox (1990a), McRae (1986/87) and Mayne (1986/87) describe the political, financial and personal issues within the Government and BCNZ that led to a fatal blow. The BCNZ withdrew its offer just before ABS was due to make its case, and without financial guarantees, ABS lost the bid. (McRae 1986/87; Walker 1990). However, the ABS application exposed the lack of Māori content in the other bids, and the other bidders subsequently improved their Māori-content proposals (Mayne, 1986/87; Walker, 1990; Fox 1990a.) The eventual winner, privately-owned TV3, began transmission on UHF and VHF in November 1989, and was required, among other things, to ensure $27-30 \%$ of its programming was locally produced. (Ministry of Culture and Heritage, 2003, p. 9). NZOA figures show that TV3 has not become a major provider of Māori programming, recording three first-run hours in 1999 and 53 in 2009, well behind MTS and TVNZ. (NZOA 2010, p $17)$. 
In 1985, desperately concerned about the state of te reo Māori, Huirangi Waikerepuru, the chairman of Ngā Kaiwhakapūmau i te Reo, led the Reo Māori Claim (Wai-11) to the Waitangi Tribunal. The case claimed official recognition of the language and alleged that the Crown had failed to protect te reo as required by Article 2 of the Treaty of Waitangi (Waitangi Tribunal, 1986). The Tribunal had to determine whether language was a taonga that the Crown was obliged to protect under the Treaty of Waitangi (Walker, 268). The answer, in 1986, was yes.

Speaking about broadcasting, the tribunal (Waitangi Tribunal, 1986) said:

... It is consistent with the principles of the Treaty that the language and matters of Maori interest should have a secure place in broadcasting ( $p$ 63).

Among its recommendations for concrete action was that broadcasting policy be formulated to recognise the obligation of the Crown to "recognise and protect the Māori language" (p 76). The Government could no longer sit on its hands. As a result of Wai-11, the Māori Language Act, which made te reo an official language of New Zealand, was passed in 1987. This legislation also conferred the right to speak Māori in legal proceedings and set up Te Taura Whiri o te Reo Māori (the Māori Language Commission), with a mandate to promote and preserve te reo. (New Zealand Government, 2007).

TVNZ made steps, too, with the appointment of the Ripeka Evans in 1986 to advise about Māori programming and staffing to the chief executive. As a result of her advice (Evans, 1989), TVNZ set two "minimalist goals" (p. 18), one to achieve 10 per cent Māori content across both channels and increase Māori staffing to 10 per cent. Evans (ibid.) saw raising the number of Māori staff as critical to increasing Māori content in programming:

... If not, we are recreating the brown-skinned Pākehā syndrome. The effects of television on the hearts and minds of our present and future generations is quite incredible, and if we continue the re-colonisation 
process, then we may we well dispense with being Māori (p19).

At the end of 1986, long-time TVNZ employee Ernie Leonard recruited Whai Ngata to start up TVNZ's Maori department (NZ On Screen, 2010), which Dunleavy (2008) describes as establishing a permanent space for te reo television broadcasting and a way to "build the experience of what became an influential group of Maori producers and directors" (p. 802). With Department of Māori Affairs help, TVNZ undertook a training programme, Kimihia, which targeted Māori for producer training (Evans, 1989). Three who benefited were Tainui Stephens, Brendon Butt and Janine Morrell (Reweti, 2008, p. 182).

The Māori Affairs Department, the Ministry of Education and TVNZ agreed to support a team of eight to start the reoonly, hour-long magazine programme Waka Huia in 1987; it still runs today (TPK, 2008). According to Stephens (2002), its aim was to "preserve the reo and mātauranga Māori of our tribal elders" (p. 109). Waka Huia was devised as a result of the influential Te Māori exhibition in the United States, which prompted Whai Ngata and Ernie Leonard (TVNZ n.d.) to reflect on the consequences if a plane-load of kaumatua returning from the US fell out of the sky. Waka Huia, says Stephens (op. cit.), has "created a vital and important audiovisual archive of iwi and hapū life and history" (p.108).

Marae, an hour-long magazine programme covering Māori society, culture, sport and politics in English, was the successor to Koha and started broadcasting on Sunday mornings in 1990 (Stephens, op.cit.). The department also produced a range of Māori-subject programmes such as the eight-part docudrama Pounamu (1992) which looked at historical figures. Although many authors have identified Sunday mornings as a viewer "dead zone" - this the only part of the week where there are no advertisements, so is noncommercial - Stephens (op. cit.) argues that an hour-long programme at this time really is an hour, and that in the early days of Marae and Waka Huia this gave directors the creative freedom to innovate, experiment and train staff. 
However, according to Fox (2001), by 1993, "the number of Māori or Māori-related programmes on television [remained] less than one per cent of the total broadcast time" (p. 261) and the call for a national Māori TV voice was becoming more strident (Stephens, 2002; Fox, 2002).

Deregulation of the broadcasting sector continued, and Māori were spurred to action once more by the so-called "broadcasting assets case", a series of 14 legal actions that went right through to the Privy Council in London, then New Zealand's court of last resort. (Horrocks, 2002; Archie, 2007). The Government's Broadcasting Amendment Act (No 2) 1989 enabled it to commercialise radio and television broadcasting assets by transferring them to the newly-created state-owned enterprises Radio New Zealand (RNZ) and Television New Zealand (TVNZ). On the basis of the Waitangi Tribunal's findings in Wai 11, the New Zealand Māori Council and Ngā Kaiwhakapūmau i te Reo, fearing a complete loss of access to the airwaves, took out an injunction (Wai 150, Wai 26) preventing the Crown from acting until provision was made for Māori broadcasting (Stephens, 2002; Fox, 2002). According to Vercoe and Williams (1994):

...They could see that the transfer didn't mesh in with the Crown's treaty obligations to protect taonga ... they said ... that broadcasting is central to the survival of the Māori language; that the transfer of assets would undermine the language unless there was a system in place to protect the language; and that therefore the transfer of assets was in breach of the treaty (p 51).

The Waitangi Tribunal granted a judicial review, but the Government was unmoved and the case went to the High Court. In May 1991, the courts deemed adequate the Government's provision for radio promotion of te reo Māori the reservation of frequencies for a network of Māori radio stations - and allowed the transfer of radio assets (Waitangi Tribunal 1999; Archie 2007).

But Justice McGechan was "not satisfied" with the Crown's performance or proposals for television and required 
the Crown to consult with Māori and return to court with new plans (Waitangi Tribunal 1999, p 15). Cabinet formulated a list of undertakings, among them that $\$ 13$ million would to be put towards promoting Maori language, which could be used to develop Māori television; the Crown would negotiate with TVNZ and RNZ to guarantee access to transmission and production facilities and Maori archival material; an analytical survey of language revitalisation policies would be done; a Maori broadcasting funding agency would be established; and a time frame for the development of policy on special-purpose Maori television and for the extension of Maori language programming on mainstream television would be decided (Waitangi Tribunal, 1999).

Still not satisfied, Māori took the case to the Court of Appeal, then to New Zealand's court of last resort, the Privy Council in London. There the case was dismissed (Vercoe and Williams, 1994; Horrocks 2002; Stephens, 2002). However, the law lords declared that in permitting the asset transfer, the Government was not spared the fulfilment of its promises.(Vercoe and Williams, 1994).

As a result, the autonomous Crown entity the Broadcasting Commission, better known as New Zealand on Air, was born (Ministry of Commerce, 1997). It offers contestable funding to all national free-to-air broadcasters (as of 2010, there are eight: TV1, TV2, TVNZ6, TVNZ 7, TV3, C4, Prime and MTS). In particular, NZOA earmarked funds for Māori radio and television programming in both Māori and English (Norris, 2004; Dunleavy, 2008), its obligation "promoting programmes about New Zealand and New Zealand interests ... and promoting Maori language and Maori culture" (Broadcasting Act 1989, s. 36 (1)).

An amendment to the Act split off from NZOA a new Maori broadcasting funding agency, Te Reo Whakapuaki Irirangi, later named Te Māngai Pāho (TMP). It began operations in 1995, funded by 14.4 per cent of the annual fees paid by the owners of television sets up until 2000 (Ministry of Commerce, 1997), when funds began to come from general taxation (Te Māngai Pāho, 2009b). TMP's role was to promote Māori language and Māori culture by "making funds available on the terms and conditions that it thinks fit", suggesting a certain 
autonomy, for broadcasting, producing programmes for broadcasting; and archiving (Broadcasting Act 1989, s. 53B).

Given the youthfulness of the Māori population, programming for children and young people in te reo Māori is an important part of the mix TMP seeks to support. Popular programmes in recent years include Pūkoro and Haa (MTS) and Pükana, which is made for TV3 and rebroadcast on MTS. Language-lesson programmes have included Ako (MTS) and TV2's Korero Mai: Speak to Me (NZOA 2010).

However, TMP's arrival was not a sign that NZOA was backing out of supporting Māori or reo-focused programming; rather, it sees itself as complementary to TMP. NZOA's Rautaki Mãori (NZOA, 2008) states one objective as supporting the production of quality, mostly English-language Maori programmes for a general audience in prime time. Its work promoting te reo "will focus on encouraging its use on mainstream channels" (p. 1). It defines Māori programmes as follows:

...A Māori programme is one that makes a conscious effort to reveal something of the past, present or future Māori world. For authenticity, at least two of the three key roles of producer, director and writer/researcher must be Māori (ibid.).

For the long-running documentary series Inside New Zealand (TV3) and Documentary New Zealand (TVNZ), it introduced a quota to ensure that at least 15 per cent of the individual documentaries had Māori creative control and Māori-related subject matter (Horrocks 2002; Norris 2004). Horrocks reports that broadcasters initially resisted the idea of a quota, "but learned to live with it on the condition that the programs remained accessible to the general audience" (p 36).

\section{Te Whanake: Laying the Foundations}

Horrocks (2002) describes the growth of Māori television production as the most positive aspect of New Zealand public service broadcasting in the years from 1995 to 1999. Certainly, under pressure to live up to its promises, the 
Government was taking action, and between 1991 and 1996 consulted with Māori several times (Ministry of Commerce, 1997a).

In 1996, a joint Māori/Crown working party on Māori television was established to focus on identifying the critical issues around policy. Four subsequent consultation hui in June and July 1997 established that Māori saw stand-alone, national Maori television as one of the three basic tenets of broadcasting policy, the others (Joint Maori/Crown Working Group on Māori Broadcasting Policy, 1996) being Māori radio and "mainstreaming", defined as:

... Broadcasting which has the effect of raising the profile/status/mana of Maori language and culture and enhancing their recognition as a part of everyday life, and presenting the Maori language as one which has relevance, is significant, is worth learning, and provides all New Zealanders with access to a Maori view of the world in its full complexity (p 4).

The country's first Māori-oriented television service, Aotearoa Television, ran as a pilot from May-October 1996, then as an Auckland regional television service to February 1997 (Ministry of Commerce, 1997). But its life was short and fraught after Te Māngai Pāho called for tenders for a free-to-air trial service of an Auckland UHF Māori television channel in early 1996 (Ministry of Commerce, 1997). According to Burns (1997) the timeframes were very tight, and the financial resources slender: the requirement was to provide three hours of original Maori television seven nights a week for thirteen weeks for $\$ 2.6 \mathrm{~m}$ including GST. The winner of the contract with TMP was to be announced on 7 March with a broadcast start date of May 1, giving the winner just seven weeks to set up offices, employ staff and train them, and make programmes:

...Virtually everybody in the industry, including Māori broadcasters, said it couldn't be done (ibid., p. 12). 
Puhi Rangiaho, Tawini Rangahau, Morehu McDonald, Robert Pouwhare and Tukuroirangi Morgan, calling their bid Aotearoa Television, won the tender and started with high hopes. The leadership wanted to work in a consensual, Māori way without a hierarchy, but factionalism between Tūhoe and Tainui groupings caused tensions from the start, and there was a lack of appreciation for transparency, good governance and sound administration. Compounding matters, the transmitter purchased by a budget-conscious TMP was lowpower (500-watts) which meant Aucklanders in the transmission area often got poor or no coverage (Burns 1997; Clifton 1997).

Although Horrocks (2002) argues that the channel "produced some interesting programming" (p. 36), the experiment ultimately ended in controversy, amid accusations of poor government planning, chronic under-funding and a political and media scrum over perceived spending irregularities which were never proved by a Serious Fraud Office investigation (Burns 1997; Serious Fraud Office, quoted in Burns 2007; Bell and Guyan 1997; Horrocks 2002). According to Burns (1997), the Government set up the pilot to fail:

...The most poignant fact in this whole saga is that, measured according to its delivery of quality television programmes, Aotearoa Television did not fail the Māori people ... the Government, and even more so, the [Opposition] Labour party, killed Aotearoa Television, and the television and print media put the nails in the coffin and buried it (op.cit., p.7).

However, lessons were learned, observes Dunleavy (2008):

...What the failure of ATN taught politicians, policymakers and Maori broadcasters was that the next time an indigenous network was attempted it would require a more appropriate public funding package that could be sustained over several years (p. 805). 


\section{Ka Puawai: The Genesis of Māori Television Service}

In 1998, the Government announced funding for a dedicated Maori TV channel and increased TMP's funding (Parliamentary Library, 2000). By July 2000, it had formulated a set of objectives to guide Māori broadcasting policy.. The first objective (Ministry of Culture and Heritage, 2003) was:

...Ensuring all New Zealanders have reasonable and regular access to

broadcasting representing the uniqueness and diversity of New Zealand life, recognising that the histories and stories of whānau, hapū and iwi are integral to any description of that life (p.13).

In mid-2001, the Government announced the establishment of a Crown-owned Māori Television Service, working through the foundation issues with Te Awhiorangi (Te Reo Māori Television Trust), which was later dissolved for a board to take its place. It took some time to resolve complex issues around ownership and funds (Milne, 2001; Fisher, 2003). There is documented evidence that roadblocks such as media and political ill-will and legislative inertia prevented the station going to air as planned in mid-2002 (Matthews 2002; Smith and Abel 2008). Other controversies dogged the channel before it went to air, among them a dispute over the transmission platform (Berry 2002; Horrocks, 2002), the sacking and jailing of the first chief executive, Canadian John Davy, six weeks into the job after it was discovered he had he had falsified his resume (Cleave, 2002); and the 2003 departure, under a cloud, of the second chief executive, Derek Fox (Kiriona, 2004).

The Māori Television Service Act 2003 (Te Aratuku Whakaata Irirangi Māori) was finally passed in May 2003 and established the channel as a statutory corporation. Its function (Māori Television Service Act 2003) was to:

...Promote te reo Māori me ngā tikanga Māori through the provision of a high quality, cost-effective Māori television service, in both Māori and English, that informs, educates, and entertains a broad viewing audience, and, in 
doing so, enriches New Zealand's society, culture, and heritage (s. 8 (1).)

The service also had to:

...ensure that during prime time it broadcasts mainly in te reo Māori; and ensure that at other times it broadcasts a substantial proportion of its programmes in te reo Māori; and ensure that, in its programming, the Service has regard to the needs and preferences of children participating in te reo Māori immersion education; and all persons learning te reo Māori; and provide broadcast services that are technically available throughout New Zealand and practicably accessible to as many people as is reasonably possible (ibid., s. 8 (2).)

The Government guaranteed funding for its first four years (Horrocks, 2002). MTS funding comes from two sources: direct bulk funding from the Government ( $\$ 16.5$ million in the year to June 30,2009 ) and TMP to fund in-house programme production \$(16.1 million). Māori Television Service (MTS) also competes for funding from TMP and NZOA, which have been providing about another $\$ 20$ million (MTS, 2009).

MTS is run by a seven-member board of directors, three appointed by the shareholding ministers (the Minister of Finance and the Minister of Māori Affairs) and four appointed by Te Pūtahi Paoho (the Māori Electoral College), which represents a number of national Māori organisations including Te Kōhanga Reo National Trust, Ngā Kaiwhakapūmau i te Reo Māori, the Māori programme-makers' body Ngā Aho Whakaari and the National Māori Council (MTS, 2009). The chairperson is a Crown appointment. Paul (2005) describes this joint Crown/Māori working partnership as a first of its kind for the industry, and adds:

...As a new network we have the prospect to change the paradigm and reflect ourselves, not someone else's version of who we should be (p 43).

TVNZ responded to MTS' arrival by appointing Hone Edwards as kaihautū (director) of Maori programming in 2003 
(Middleton, 2003). The position was made redundant in 2007 with TVNZ head Rick Ellis arguing that his managers were ready to take responsibility for Maori content across the board (Trevett, 2007).

An "unashamedly pro-Māori" channel, Māori Television, as the broadcaster is known, started transmission on March 28, 2004 (Harawira, 2008). In its first year, the channel aired nearly eight hours of programming a day, of which four hours were original shows. A total of $70 \%$ of the content was in te reo Māori (ibid). However, MTS aimed to provide something for everything, as evidenced by its branding "mā rātou, mā mātou, mā koutou, mā tātou" (for them, for us, for you, for everyone), which Smith and Abel (2008) cite as proof of the station's "nation-building agenda" (p. 8).

Ratings for the first 12 weeks showed that 358,000 people watched Māori Television, 65 per cent of them non-Māori (Stokes, 2004). Marae makeover show Marae DIY, language show Körero Mai and food show Kai Time on the Road, all prime-time programming, dominated the ratings (ibid). Reviewer Diana Wichtel (2004) described the channel as "the chance to look at the country through a different set of eyes" (p.79). Another author (Hume 2009) described its programming as "folksy, warm-hearted ... It's cheap, fresh and honest television - the antithesis of much content on our screens - and it is finding admirers" (p C6).

However, the technical quality of some programmes in MTS' first year was uneven. The channel still struggles with a shortage of well-informed interviewees who speak te reo and a shortage of experienced interviewers (Harawira, 2008). At the time and since, there has been criticism of the quality of the language. (ibid.; TPK 2009). Harawira (ibid.) observes that new words to describe contemporary issues can "confuse the ears" of native speakers, and that it will take time to find balance between the language of brief news grabs and classical Māori (p 5).

A number of authors and commentators have described MTS as a successful broadcaster with a strong and attractive public service focus (Smith and Abel 2008; Nicol Reed 2006; Herald on Sunday, 2007). AGB Nielsen Media Research figures show that two million people tuned in during April 2010 (MTS 
2010). MTS says that after five years of the service, more than two-thirds of viewers remain non-Māori (MTS 2009e).

A report on the economic impact of MTS and associated activities claimed that the channel had made a positive contribution to GDP, had increased career opportunities for fluent speakers and expanded the pool of indigenous broadcasters (BERL, 2009). MTS calculates that each year since 2004, between 500 and 600 full-time equivalent jobs have resulted from its activities and the independent production industry (MTS 2009d). However, swift growth has also brought challenges (Paul, 2005):

Problems include some companies struggling to meet the demands of the new station, or deliver quality programming on time and on budget. The new station has created the conditions for the empowerment of Maori to the industry and also has to cope with the many who have not taken the time to learn the tools and time-honoured techniques of good television making. Instead, the latter become overnight producer/directors and often flounder as a result (p.44).

The legislation that set up MTS required review after five years. An independent review (Te Kāhui o Māhutonga, 2009) found that the legislation was generally appropriate for MTS' establishment phase but, among other things, recommended that a definition of quality language be added to the Act. This will necessitate the development of new benchmarks between TMP, MTS and other stakeholders (TMP, 2009). In a separate development, a MTS Māori language strategy is also being devised (MTS, 2009a) to link in with the all-of-Government Māori Language Strategy, a blueprint for language revitalisation activities (Te Puni Kōkiri, 2003).

TVNZ and MTS have developed a competitive and at times adversarial relationship (Mather, quoted in MTS 2007).MTS has also staked a claim to the public broadcasting space it feels is not well-served by the state-owned broadcaster, investing heavily in its well-received Anzac Day specials (Mather, quoted in Rae, 2008). In 2007, TVNZ announced it would increase the breadth of Māori content on its channels (Tahana, 2007), making the internal appointment of Kathryn 
Graham to oversee the expansion (Te Māngai Pāho, 2009b). MTS responded by saying that TVNZ's plan was a "threat to Maori Television's future and to its funding base" (MTS, 2007, para. 2), but it is not clear that this has come to pass.

Viewers benefit from this competition. To mark the 25th anniversary of Te Karere in March 2009, Television New Zealand extended the programme to a commercial half-hour. However, Te Karere and other Māori-language programming on TV1 and TV2 remains confined to off-peak slots. (NZOA, 2010). TV1 broadcasts Te Karere live at $4 \mathrm{pm}$ every weekday afternoon; a repeat, with NZOA-funded English subtitles added, is shown at around 6am the following morning. Marae runs at 8am-9am on Sunday; parts of the programme carry English sub-titles. Waka Huia runs on Sunday from 10am11 am. (TMP 2009; TVNZ n.d.).

However, the means to access Māori-language broadcasting are extending far beyond the television, with new technology developing multiple platforms to disseminate content. Digital transmission - technology that creates greater choice and better-quality images and sound - is the new horizon; the second is the proliferation of viewer-controlled platforms from the internet to cellphones.

In 2007, as a non-for-profit cooperative, TVNZ, TVWorks (the owner of TV3 and C4), MTS and RNZ were among the coalition of broadcasters which began the switch to digital television and radio with the launch of the Freeview platform (Maharey 2007), which requires viewer purchase of a digital receiver (Freeview, 2010.) MTS' 100\% reo channel, Te Reo, began in March 2008 with new Government funding to enable the channel to pursue its digital strategy. (MTS 2007). Te Reo broadcasts $7-10 \mathrm{pm}$ seven days a week without subtitles or advertising, and aims to serve viewers who seek a fullimmersion experience (MTS 2009c, 2009d). MTS has the capacity to launch another two digital channels and is assessing the potential. Other delivery-platform possibilities include mobile TV and links between TV broadcasts and mobile phones (Mather, quoted in Rae 2008).

TVNZ now has two digital channels, TVNZ6, launched in October 2007, and TVNZ7, launched in March 2008 (TVNZ 2010); MTS and TVNZ digital channels repeat their parent 
company's Māori-language content. In March 2009, TV3 set up TV3+1, which runs TV3 content one hour later. (Freeview, 2010). No date has yet been set for complete switch-over to digital, but it is expected the analogue system will be shut down by 2015 (Maharey 2007; NZTBC, 2010).

On-demand broadcasting via the internet has further widened choice for viewers seeking Māori-language programmes; TVNZ, TV3 and MTS websites all provide ondemand viewing of local content. The choice they provide and the accompanying viewer fragmentation would seem to make reo Māori mainstreaming a less critical concept than in the past. On-demand viewing also breaks down barriers to access; Australian viewers now account for $20 \%$ of MTS' growing online audience (Hendery, 2010).

The amount of Māori programming on national free-to-air television has risen from 131 hours in 1988, when there were two channels, to 3153 hours across six free-to-air channels in the year to June 2009; Prime and C4 continue to have minimal Māori content (NZOA, 2010). Stringent broadcaster reporting requirements show clearly the frequency of te reo Māori on free-to-air television. TMP (2009) last year announced that in its 15 years of existence, it had funded 500,000 hours of television broadcasting in te reo.

\section{He Ao Hou: Conclusion}

As we have seen, Māori were almost invisible in the early days of television in the 1960s, represented largely as singers and dancers in a light-entertainment studio format. Inattention to Māori language and a broad reflection of tikanga can be seen as a manifestation of the belief that Māori were assimilating into the Pākehā population, retaining vestiges of reo and tikanga. At the time New Zealand got its first television channel, te reo Māori was in a seriously endangered state, among its predators pro-English education policies, rapid urbanisation, and English-saturated media.

Some of the notable early efforts to represent Māori themes came from independent producers working within a Māori world-view; however, they were subject to the whims of a twochannel television system marked by tight Government control 
and a distinctly ad-hoc approach to Māori-language broadcasting.

Activists for the preservation and growth of te reo Māori realised that their fight had two fronts: firstly, securing funding and resources to create content, and secondly, securing a mechanism to preserve access to the means of television broadcasting. As two large petitions in the 1970s had not succeeded in encouraging Government attention to Māori language-broadcasting issues, Māori resorted to legal instruments such as the Waitangi Tribunal, the High Court, the Court of Appeal and the Privy Council in the United Kingdom. Māori organisations showed great perseverance in order to claim and then protect access to the means of broadcasting in a unsupportive political climate.

The Government's early efforts to respond - such as a Māori-Crown bid for a third channel and the pilot for a Māori channel - were isolated and under-funded measures rather than the expression of a coherent, long-term strategy underpinned by solid foundations. Political ill-will and legislative inaction further frustrated Māori, but the new millennium brought with it a consultative approach.

Māori Television, now six years old, is the culmination of political will, first of Māori, then of successive Governments forced to acknowledge their Treaty obligations and make this acknowledgement into law. In recognition that Māori-language programming is not easily commoditised, a dedicated Māori broadcasting funder has been a critical factor in the increase in reo programming on New Zealand's televisions. The end result has been the preservation and extension of the state broadcaster's early Māori-language programmes and an indigenous broadcaster which appears to be succeeding in its goal to promote and preserve te reo Māori in a variety of styles to a diverse audience.

The advent of Māori Television has also introduced an element of competition to the New Zealand broadcasting sector, with Crown-owned broadcaster taking steps to invest in Māori-language programming. The new broadcasting environment has also spurred the growth of an independent, Māori-oriented television production industry, providing a broader skill base for film and television production in general 
in New Zealand. However, broadcasting policy and funding have ensured that broadcasting in te reo is not a separatist notion, excluding large numbers of New Zealanders; various policies ensure funding for sub-titling.

New technology is offering multiple platforms for viewers to access Māori-language content, reducing the importance of "mainstreaming" in the argument for Māori representation on screen. Māori are no longer invisible on the small screen, and te reo Māori is now much more than a staple of song-anddance shows. A great deal has changed since Howard Morrison faced the camera one night in 1960. 


\section{Bibliography}

Abel, S. (1997). Shaping the News: Waitangi Day on Television.

Auckland: Auckland University Press.

Abel, S. (2001). Carol Archie: Reporting as an Alternative Discourse. In J. Farnsworth and I. Hutchison (Eds.), New Zealand Television: A Reader (pp. 111-18). Palmerston North: Dunmore Press.

Archie, C. (1997). Pou Kōrero. Wellington: New Zealand Journalists' Training Organisation.

Belich, J. (2001). Paradise Reforged. Auckland: Penguin Books.

Benton, R. (1997). The Mãori Language: Dying or Reviving? Wellington: New Zealand Council for Educational Research.

Barclay, B.(1990) Our own image. In J. Farnsworth and I. Hutchison (Eds.),

New Zealand Television: A Reader (pp. 104-110). Palmerston North: Dunmore Press.

Bell, C., Guyan, C. (1997, February 18). 'Bloody' debate on Maori TV expected. The Dominion (2nd ed.). Retrieved May 3, 2010, from Proquest Central database.

Benton, R, (1984). Bilingual Education and the Survival of the Māori Language. The Journal of the Polynesian Society, 93(247-266). Retrieved April 29, 2010, from http://www.jps.auckland.ac.nz/document/Volume_93_1984/Vol ume_93\%2C_No._3/Bilingual_education_and_the_survival_of_the Maori_language\%2C_by_R._A._Benton\%2C_p_247-266/

Broadcasting Act 1989. Retrieved May 3, 2010, from

http:/ /www.legislation.govt.nz/act/public/1989/0025/latest /DLM155365.html

Business and Economic Research (BERL) (2009). Māori Television and its Contribution to the New Zealand Economy. Retrieved May 3, 2010, from http://www.berl.co.nz/886a1.page

Berry, R. (1999, December 23). Govt delays stymie Māori TV. Evening Post. Retrieved May 2, 2010, from Proquest Central database.

Berry, R. (2001, July 23). It's all go for Maori TV service. Evening Post. Retrieved May 2, 2010, from Proquest Central database.

BERRY, R. (2002, DECEMBER 14). REJECTION OF MAORI TV BID EXPECTED. DOMINION POST. RETRIEVED MAY 3, 2010, FROM PROQUEST CENTRAL DATABASE.

BERRY, R. (2003, AUGST 25). FOX SICK OF BEING ON FRONT PAGE. NEW ZEALAND HERALD. RETRIEVED MAY 3, 2010, FROM

HTTP:/ /WWW.NZHERALD.CO.NZ/NZ/NEWS/ARTICLE.CFM?C_ID=1\&OBJE CTID $=3519783$

Boyd-Bell, R.(1985). New Zealand Television: The First 25 Years. Auckland: Reed Methuen Publishers.

Broadcasting Standards Authority (2005). The Portrayal of Māori and Te Ao Māori in Broadcasting: The foreshore and seabed issue. Retrieved April 30, 2010 from http://www.bsa.govt.nz/publications/BSA-PortrayalofMaori.pdf 
Broadcasting Standards Authority (2009). Maori Worldviews and Broadcasting Standards: What should be the relationship? Retrieved April 19, 2010, from http://www.bsa.govt.nz/index.php

Burns, D. (1997). Public Money, Private Lives: Aotearoa Television - The Inside Story. Auckland: Reed.

Carter, A. (1992, February 10). Doing it Their Way. New Zealand Listener, 132 (2706), 56-57.

Cleave, L.(2002, May 29). John Davy sent to prison for eight months. New Zealand Herald. Retrieved April 29, 2010, from http://www.nzherald.co.nz/nz/news/article.cfm?c_id=1\&objectid $=2043885$

Clifton, J. (1997, February 15). Television Whodunit. New Zealand Listener, 157 (2965) 16-17.

Comrie M. and McGregor J. (1992). Whose News? Palmerston North: Dunmore Press.

Dunleavy, T. (2008). New Zealand television and the struggle for 'public service'.

Media Culture Society (30)6, 795-811. Downloaded April 20, 2010, from SAGE Communication Studies Full-Text Collection.

Evans, R. (1989). Māori Television. Race, Gender, Class 9/ 10, 16-23.

Fisher, D. (2003, June 29). 'Te Blowout' at Māori television criticised as 'expensive' by Treasury. Sunday Star-Times. Retrieved May 3, 2010, from Proquest Central database.

Fox, D. (1990a). Aotearoa Broadcasting System, Inc. In P. Spoonley and W. Hirsch (Eds.), Between the Lines: Racism and the New Zealand Media (pp. 128-133). Auckland. Heinemann Reed.

Fox D. (1990b) Te Karere: The Struggle for Māori News. In P. Spoonley and W.Hirsch (Eds.), Between the Lines: Racism and the New Zealand Media (pp. 103-107). Auckland. Heinemann Reed.

Fox D. (1992). The Maori Perspective of the News. In M. Comrie and J. McGregor (Eds.), Whose News? (pp. 170-180). Palmerston North: Dunmore Press.

Fox, D. (2002). Honouring the Treaty: Indigenous Television in Aotearoa. In J. Farnsworth and I. Hutchison (Eds.), New Zealand Television: A Reader (pp. 260-269). Palmerston North: Dunmore Press.

Freeview (n.d.). What is Digital TV? Retrieved May 9, 2010, from http://www.freeviewnz.tv/all_about_freeview/page/what_is_digita 1_tv

Haines, L. (2004, March 30). The Promise of Māori Television. Manawatu Evening Standard. Retrieved May 2, 2010, from Australia/New Zealand Reference Centre.

Hay, D. (1996). Giving/Taking, Selling/Buying, Speaking/Silence: Te reo Māori in primetime. Continuum,10(1) 94-107. Retrieved April 23, 2010, from Informit database.

Harawira, W. (2008, April 16). Challenges Facing Indigenous Broadcasters. Speech delivered to Pacific Media Summit, April 16-18, 2008, Apia, Samoa. Retrieved April 23, 2010, from www.hrc.co.nz/hrc_new/hrc/cms/files/documents/23-Apr- 
2008_11-50-04_Challenges_facing_indigenous_broadcastersWena_Harawira.doc

Hendery S. (2010, February 19). More Kiwis overseas tuning in to Māori Television's revamped website. Retrieved May 9, 2010, from http://www.nzherald.co.nz/business/news/article.cfm?c_id=3\&o bjectid=1062 7027

Hollings, M. (2005). Māori Language Broadcasting: Panacea or Pipedream. In Languages of New Zealand (pp. 111-130).

Wellington: Victoria University Press.

Horrocks, R. (2004). The History of New Zealand Television: An Expensive Medium for a Small Country. In R. Horrocks and N. Perry (Eds.), Television in New Zealand: Programming the Nation (pp. 20-43). Melbourne: Oxford University Press.

Hubbard, A. (2004, March 28). Taonga in your Living Room. Sunday Star-Times. Retrieved May 2, 2010, from Australia/New Zealand Reference Centre database.

Hume T. (2009, March 22). Low Budget, High Ideals. Sunday StarTimes. Retrieved May 2, 2010, from Australia/New Zealand Reference Centre database.

Hunn, J. (1961). Report on Department of Māori Affairs. Wellington: R. E. Owen, Government Printer.

Joint Maori/Crown Working Group on Māori Broadcasting Policy (1996). Report of the Joint Maori/Crown Working Group on Mãori Broadcasting Policy. Retrieved May 5, 2010, from http://www.med.govt.nz/upload/15494/report1.pdf

King, M. (2003). The Penguin History of New Zealand. Auckland: Penguin Group.

Kiriona, R. (2004, March 20). Doubters told to wait for Māori TV launch. New Zealand Herald. Retrieved April 20, 2010, from http://www.nzherald.co.nz/nz/news/article.cfm?c_id=1\&objectid $=3555817$

Kupu Taea: Media and Te Tiriti Project (2007). Media and Te Tiriti o Waitangi 2007. Retrieved May 6, 2010, from http://www.trc.org.nz/sites/trc.org.nz/files/report2007_0.pdf

Maharey, S. (2007, May 2). Launch of Freeview [speech]. Retrieved May 10, 2010 from http://www.beehive.govt.nz/node/29156

Maori Language Act 1987. Retrieved April 30, 2010, from http://www.legislation.govt.nz/act/public/1987/0176/latest/DL M124116.html\#DLM124120

Māori Television Service (Te Aratuku Whakaata Irirangi Māori) Act 2003. Retrieved April 30, 2010 from http://www.legislation.govt.nz/act/public/2003/0021/latest/DL M193696.html

Māori Television Service (2007, August 31). Māori Television Response to TVNZ Māori Strategy (press release). Retrieved April 30, 2010, from http: / / media.maoritelevision.com/default.aspx?tabid=198\&pid=3 82 
Māori Television Service (2007). Annual Report. Retrieved May 20, 2010 from

http:// corporate.maoritelevision.com/LinkClick.aspx?fileticket=_k kKiSBhXmc\%3d\&tabid $=170$

Māori Television Service (2009a). Annual Report. Retrieved April 30, 2010, from http:/ / corporate.maoritelevision.com/LinkClick.aspx?fileticket=A Wp4FepQqs8\%3d\&tabid=170

Māori Television Service (2009b). Pānui Whāinga: Statement of Intent. Retrieved April 30, 2010, from http:/ / corporate. $m a o r i t e l e v i s i o n . c o m / L i n k C l i c k . a s p x ? f i l e t i c k e t=r 4$ cFj1_cLo8\%3d\&tabid=170

Māori Television Service (2009c). Corporate Profile 2009. Downloaded May 5, 2010, from

http://corporate.maoritelevision.com/LinkClick.aspx?fileticket=E 24IatROQOs \%3d\&tabid $=170$

Māori Television Service (2009d). Māori Television Fact Sheet.

Retrieved April 30, 2010, from id $=1598$

http://media.maoritelevision.com/default.aspx?tabid=198\&p

Māori Television Service (2009e). Māori Television Rocks the Ratings (Press release). Retrieved May 6, 2010, from http://media.maoritelevision.com/default.aspx?tabid=198\&pid=3 81

Māori Television Service (2010). Māori Television marks two million milestone (Press release). Retrieved May 5, 2010, from http:/ / media. maoritelevision.com/default.aspx?tabid=400\&pid $=7$ 079

Matthews, P. (2002, June 8). Now for the Hard Part. New Zealand Listener, 184(3239) 26-27.

Mayne, W. (Dec 1986/Jan 1987). The Wedding that Wasn't. Aotearoa Wooed - and Jilted. Tu Tangata 33: 42.

McRae, T. (Dec 1986/Jan 1987). Two Men, Two Different Paths. Tū Tangata 33: 34-35.

Mediaworks (2009, May 10). TV3 Plus 1 Launches on Freeview. Retrieved May 10, 2010, from http: / / www.tv3.co.nz/Default.aspx?tabid=832\&g=posts $\& \mathrm{t}=170$

Meredith, P. (2009, March 4) Urban Māori. In Te Ara - The Encyclopedia of New Zealand. Retrieved April 29, 2010, from http://www.TeAra.govt.nz/en/urban-maori/3/3 and http://www.teara.govt.nz/en/urban-maori/3/4

McGregor, J. (1991). News Values and the Reporting of Māori News. Working Paper series 91/3. Palmerston North: Department of Human Resource Management, Faculty of Business Studies, Massey University.

Middleton J. (2003, August 25). Edwards a quiet crusader but no Hone-come-lately. New Zealand Herald. Retrieved May 9, 2010, 
from

http://www.nzherald.co.nz/nz/news/article.cfm?c_id=1\&objectid $=3519776$

Milne, J. (2001, July 25). Maori TV service staves off court action. Dominion Post (2nd edition). Retrieved May 2, 2010, from Proquest Central database.

Ministry of Commerce (1997). Broadcasting Policy in New Zealand.

Retrieved May 1, 2010, from

http:/ /www.med.govt.nz/upload/12863/bpinnz.pdf

Ministry of Commerce (1997a). Kaupapa Pouaka Whakaata Mãori: Māori Broadcasting Policy Discussion Document. Retrieved May 9, 2010, from http:/ /www.med.govt.nz/upload/15494/discuss.pdf

Ministry of Commerce (1997b) Māori Television: A Summary of Views. Retrieved May 5, 2010, from

http:/ /www.med.govt.nz/upload/19104/maori_tv.pdf

Ministry of Culture and Heritage (2003). Broadcasting in New Zealand: A 2003 stock-take. Retrieved April 30, 2010, from

http://www.mch.govt.nz/publications/broad-2003/Broadcastingin-NZ.pdf

New Zealand on Air (2002). Local Content Survey 2001. Retrieved April 28, 2010,from

http://www.nzonair.govt.nz/media/11866/local_content_2001.pd $\mathrm{f}$

New Zealand on Air (2008). Te Rautaki Mãori. Retrieved May 3, 2010, from

http:/ / www.nzonair.govt.nz/media/14464/rautaki\%20maori\%20j une $\% 202008$.pdf

New Zealand on Air (2010). Local Content Survey 2009. Retrieved April 28, 2010 from

http:/ / www.nzonair.govt.nz/media/42435/local\%20content\%202 010\%20final\%203.pdf

New Zealand Television Broadcasters' Council. A Brief History of

Television Broadcasting in New Zealand. Retrieved April 19, 2010, from

http://www.nztbc.co.nz/story.php?story=story_history.inc

New Zealand on Screen. Whai Ngata. Retrieved May 5, 2010, from http://www.nzonscreen.com/person/whai-ngata/biography

New Zealand on Screen. Koha. Retrieved May 8, 2010, from http:/ / www.nzonscreen.com/title/koha$1980 /$ series?order=DESC\&sort=name

Nicol Reed, M (2006, November 19). The Little Channel That Could. Sunday Star- Times. Retrieved May 2, 2010, from Proquest Central database.

Norris, P. (2004). Reshaping Public Broadcasting: The New Zealand Experience 1988-2003. Retrieved April 28, 2010, from http:/ /www.ippr.org.uk/uploadedFiles/projects/NorrisNZ2.PDF

Parliamentary Library (2000). Background Note: Te Reo Māori - the Māori language. Retrieved May 1, 2010, from 
http://www.parliament.nz/NR/rdonlyres/CAFFFF6F-70F6-4A8299D5-C7D007312D00/428/004TeReo3.pdf

Paul J. (2005). Challenges lie ahead for MTS in the Aotearoa public sphere. Pacific Journalism Review 11(1), 42-46.

Piohipi, V. (2007). The impact of Māori Television on being Māori: A Geographical Approach. MAI Review, 2007 (1). Downloaded May 6, 2010, from http://ojs.review.mai.ac.nz/index.php/MR/article/view/37/37

Rae, F. (2008, April 26). Spreading the Word. New Zealand Listener 213(3546). Retrieved May 9, 2010, from http://www.listener.co.nz/issue/3546/features/10928/spreadin g_the_word.html

Reweti, D (2006). Māori and Broadcasting. In M. Mulholland et al. State of the Māori nation: Twenty-first-century issues in Aotearoa (pp. 179-186). Auckland: Reed.

Smith, J. and Abel, S. (2008). Ka Whawhai Tonu Mātou: Indigenous Television in Aotearoa New Zealand. New Zealand Journal of Media Studies, 11(1). Retrieved April 27, 2010, from http: / / www.nzmediastudies.org.nz/issues.php?issue $=5 \&$ title $=$ Vol ume+11+No. 1

Smith, J. (2006). Parallel Quotidian Flows: Māori Television on Air. New Zealand Journal of Media Studies, 9(2), 27-35. Retrieved April 23, 2010, from http://www.nzmediastudies.org.nz/

Spicer, B., Powell M., and Emanuel D,. (2002). A Brief History of Television in New Zealand. In J. Farnsworth and I. Hutchison (Eds). New Zealand Television: A Reader (pp. 199-210).

Palmerston North: Dunmore Press.

Spoonley, P. (1990). Racism, Race Relations and the Media. In Spoonley P. and Hirsh W. (Eds.), Between the Lines: Racism and the New Zealand Media pp 26-37. Auckland: Heinemann Reed.

Stephens, Tainui (2002). Māori Television. In R. Horrocks and N. Perry (Eds.), Television in New Zealand: Programming the Nation (pp. 107-114). Melbourne: Oxford University Press.

Stokes, J. (2004, June 25). Non-Maori fans of Māori TV. New Zealand Herald. Retrieved May 9, 2010, from http:/ /www.nzherald.co.nz/nz/news/article.cfm?c_id=1\&objectid $=3574715$

Stuart, I. (2003). The construction of a national Māori identity by Māori media. Pacific Journalism REVIEW, 9(1) 45-58.

Tahana, Y. (2007, August 31). Primetime lift for Māori at TVNZ. New Zealand Herald. Retrieved April 30, 2010, from http:/ / www.nzherald.co.nz/maori/news/article.cfm?c_id=252\&ob jectid=10460 860\&ref=bebo

Television New Zealand (2010). Television New Zealand's Channels. Retrieved May 10, 2010, from http://tvnz.co.nz/view/page/845005

Television New Zealand (n.d.) Waka Huia. Retrieved May 3, 2010, from http://tvnz.co.nz/waka-huia/695194 
Te Kāhui o Māhutonga (2009). Review of the Māori Television Service Act 2003. Retrieved May 3, 2010, from http://www.tpk.govt.nz/_documents/TKOM_MTS\%20_report_eng lish.pdf

Te Puni Kōkiri (2003). Te Rautaki Reo Māori: The Māori Language

Strategy. Retrieved May 2, 2010, from

http://www.tpk.govt.nz/en/in-print/our-

publications/publications/the-maori-language-

strategy/download/tpk-maorilangstrat-2003.pdf

Te Puni Kōkiri (2008, April-May). Kaupapa Matua: Broadcasting our Reo and Culture. Kōkiri, Paenga-whāwhā 2008. Retrieved May 5, 2010, from http://www.tpk.govt.nz/en/in-print/kokiri/kokiri-082008/tpk-kokiri8-2009.pdf

Television New Zealand (n.d.). FAQs. Retrieved May 3, 2010, from http://tvnz.co.nz/view/page/816460/869419\#controlmaoritv

Television New Zealand (Producer). (2009, July 31). Sir Howard Morrison talks about te reo Māori [Television item in Good Morning show]. Auckland: TVNZ. Retrieved April 28, 2010 from http://tvnz.co.nz/good-morning/s2009- e310709howardmorrison-video-2881548

Te Māngai Pāho (n.d.). Chronology of Events. Retrieved May 2, 2010, from http://www.tmp.govt.nz/about/events.html

Te Māngai Paho (2009a). Annual Report 2008-2009. Retrieved April 28, 2010, from http://www.tmp.govt.nz/about/20082009_TMP_Annual_Report.pdf.

Te Māngai Pāho (2009b). Statement of Intent 2009-2014. Retrieved May 9, 2010, from http://www.tmp.govt.nz/about/SOI_09.pdf

Te Māngai Pāho (2009c, March 7). Te Purapura: From the Television Funding Portfolio. Retrieved May 9, 2010, from

http://www.tmp.govt.nz/television/News_07_Mar_08.pdf

Te Rito, J. (2008). Struggles for the Māori Language: He whawhai mō te reo Māori. MAI Review, 2008:2. Retrieved April 28, 2010, from http://www.review.mai.ac.nz/index.php/MR/issue/view/ 10

Trevett, C. (2007, May 25). Maori adviser speaks up for TVNZ. New Zealand Herald. Retrieved May 9, 2010, from http:/ / www.nzherald.co.nz/maori/news/article.cfm?c_id=252\&ob jectid=10441 696\&pnum=0

Vercoe, M. and Williams, J. (1994, February/March). Showdown at Downing Street. Mana: The Māori news magazine for all New Zealanders, pp. 50-53.

Waitangi Tribunal (1986). Report of the Waitangi Tribunal on the Te Reo Mãori Claim (Wai 11). Retrieved May 4, 2010, from http: / /www.waitangitribunal.govt.nz/scripts/reports/reports/11/2580F91B-5D6F46F4-ADE0- BC27CA535C01.pdf 
Waitangi Tribunal (1999). The Radio Spectrum Management and Development Final Report (Wai 776). Retrieved May 4, 2010, from http://www.waitangitribunal.govt.nz/reports/view.asp?reportid=9 B5ED50E-E089-4D64-8961-AEA664B9A08D

Walker, R. (1990). Ka Whawhai Tonu Mātou: Struggle without End. Auckland:Penguin.

Walker R. (1990b) The Role of the press in Defining Pākehā Perceptions of the Māori. In Spoonley P. and Hirsh W. (Eds.), Between the Lines: Racism and the New Zealand Media pp. 3846. Auckland: Heinemann Reed.

Wichtel, D. (2004, April 10). Pride of Place. New Zealand Listener, 193(3335) 79.

Young, D. (1978, July 1). Māori TV: A Presence for a People. New Zealand Listener, (89)2009, 22-23. 